\title{
Study on Surface water Quality around Selected Integrated Steel and Power plant
}

\author{
O.P. Rai, R. Kushwaha ${ }^{1 *}$ and B.P. Kushwaha ${ }^{1}$ \\ Chemistry Department, Government Autonomous P.G. College Satna, (M. P.), India \\ ${ }^{1}$ Environment Department, GMR Chhattisgarh Energy Limited, Raipur, (C. G.), India
}

\begin{abstract}
The physical and chemical characteristics of pond water was investigated during Monsoon Season, Post-monsoon, winter season and Pre-monsoon (2012-13). The studied ponds relocated near about an integrated steel and power plant at Mandir Hasoud, Raipur, India. The eleven water quality parameters like $\mathrm{pH}, T D S$, alkalinity, total hardness, chloride, iron, fluoride, sulphate, nitrate, calcium and magnesium were analyzed in this study. The pH, TDS, Total Hardness, Alkalinity, Chloride, Sulphate, Nitrate, calcium and magnesium were found well within the norms as prescribed by BIS. Fluoride concentration in sample SW1, SW2 and SW4 was found to be slightly higher than desired limit but under permissible limit as prescribed by BIS. Iron concentration was found higher than permissible limit in all the samples. The higher concentration of iron may be due to deposition of iron content mixed suspended particulate matter from atmosphere to surface that is emitted from nearest an integrated steel and power plant. The maximum iron concentration found in the Serikheri pond which is situated in the down wind direction with respect to the plant where dispersion of air pollutants is greater than other location.
\end{abstract}

Keywords: Parameters, Physicochemical, Pollution, Quality, Standard.

\section{Introduction}

Water is most important natural resource for substances of life on biosphere. It is medium in which all living process occurs. Water dissolves nutrients and distributes them to cells, regulates body temperature, support structures and removes waste products. About $60 \%$ of our body is water. We can survive for weeks without food, but not only a day without water. The quality of water is vital concern for mankind since it is directly linked with human welfare. It is a matter of history that faecal pollution of drinking water causes water borne diseases, which has wiped the entire population of cities. At present, menace of water borne diseases and epidemic stills looms large on horizons of developing countries; polluted water is a culprit in all such cases. The major sources of water pollution are domestic waste from urban and rural areas, and Industrial waste, which are discharged in natural water bodies.
The history of human civilization reveals that water supply and civilization are almost synonymous. Several cities and civilization are dispersed due to water shortages originating from climate changes. Millions of peoples all over the world, particularly in the developing countries are losing their lives every year from water borne diseases (Kushwaha et al., 2008). The analysis of water both in term of quality and quantity is essential for the very existence of mankind (Abdul Razak et al., 2009; Yisa and Jimoh, 2010; Rao et al., 2012; Jena et al.; 2013). Water is mainly used for drinking, bathing, fisheries and other domestic purposes. Lack of awareness and civic sense, use of inefficient methods and technology leads to more than $50 \%$ of water wastage in domestic, agriculture and industrial sector (Nkansah, et al., 2009; Rathod et al., 2011; Mehta, 2011; Bhuvan, 2012). Water pollution is rendering much of the available water unsafe for 
Table 1 Location of sampling station.

\begin{tabular}{|l|c|c|c|}
\hline $\begin{array}{l}\text { Station } \\
\text { No. }\end{array}$ & Location & $\begin{array}{c}\text { Distance } \\
\text { from } \\
\text { industry }\end{array}$ & $\begin{array}{c}\text { Direction } \\
\text { w. r. t. } \\
\text { Industry }\end{array}$ \\
\hline SW1 & Serikheri pond & 2.10 & W \\
\hline SW2 & Nawagaon pond & 5.79 & SE \\
\hline SW3 & Kurud tank & 1.56 & NE \\
\hline SW4 & Lohra pond & 6.14 & NNW \\
\hline
\end{tabular}

consumption. In India, most of the population depends on surface water. The Chhattisgarh state is enriched with lots of ponds and rivers. Major portion of the population of this state is dependent on pond water for their daily water needs like bathing, washing clothes, cleaning utensils, irrigation etc. Rain water is collected in studied ponds through surface runoff rain water. In natural surface, if there is no pollution then water is also not polluted which collects in ponds through surface runoff rain water. But if surface is polluted by various personal and industrial activities then collected water in ponds will get polluted.

In the present study, four ponds namely Serikheri Pond, Nawagon Pond, Kurud Tank and Lohara Pond of Mandir Hasoud Region, Raipur were selected for physical and chemical analysis. All these ponds are located in buffer zone of M/s Monnet Ispat and Energy Limited Raipur, India. Locations of sampling station with respect to the above steel and power industry are given below in Table 1.

\section{Materials and Methods}

Surface water samples of four selected ponds were collected in pre-cleaned 2 liter capacity polythene bottles. The water samples were collected four times in a year in different seasons like Monsoon Season (June-August), Post-monsoon season (September-November), winter season (December-February and Pre-monsoon season (March-May) from different ponds of study area by adopting grab sampling method. Analysis was carried out according to standard method (APHA, 2012; BIS, 2012; Kushwaha, 2008; Kushwaha, 2006; Moharir, 2002). Description of sampling sites is presented in Table 1. The samples were collected and analyzed during the year 2012-13. The eleven water quality parameters were analysed in present study. The parameters are $\mathrm{pH}$, TDS, Total hardness, Alkalinity, Chloride, Iron, Fluoride, Sulphate, Nitrate, Calcium, and Magnesium. The analysis results of studied ponds are given in Figure 1 to 11 .

\section{Results and Discussion}

The physical and chemical parameters of surface water quality were analysed by adopting standard methods. The results of analysed parameter of collected water samples are given in Figure 1 to 11.

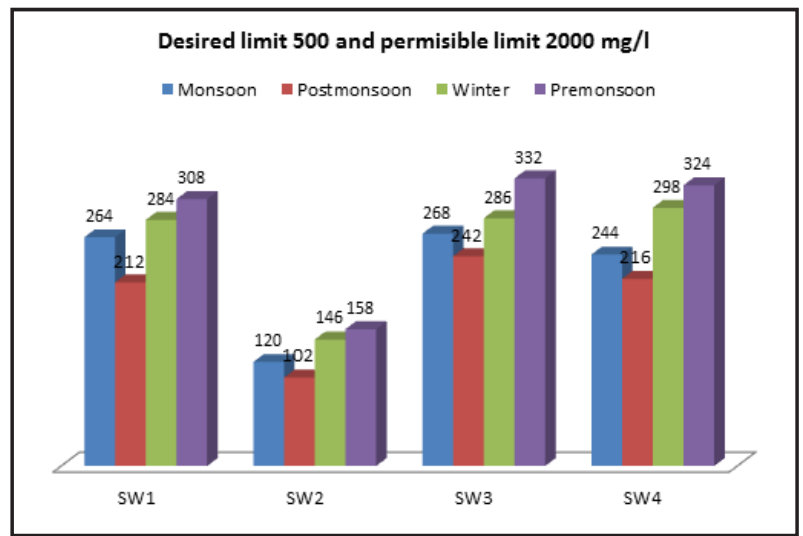

Fig. 1 TDS (mg/l) for all locations.

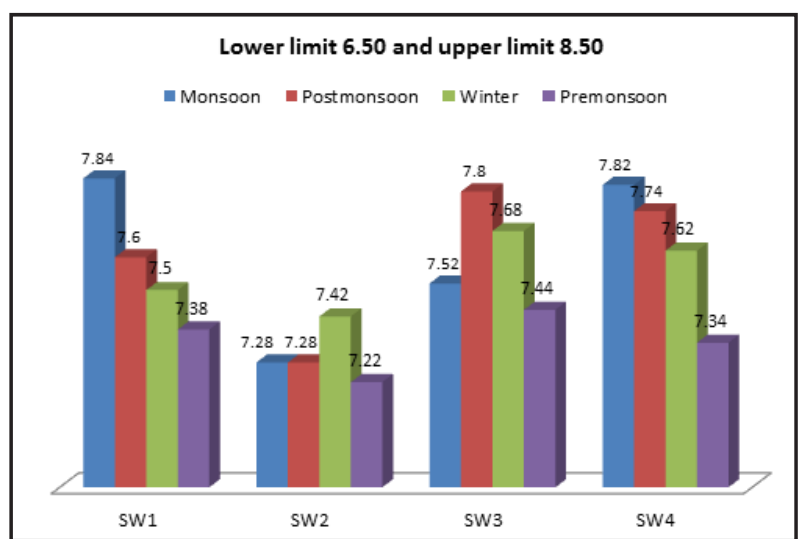

Fig. $2 \mathrm{pH}$ values for all locations. 


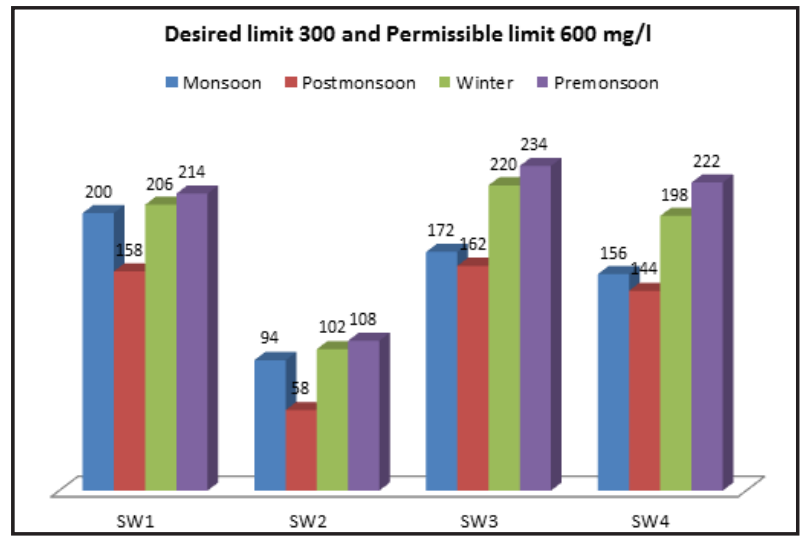

Fig. 3 Total hardness (mg/l) for all locations.

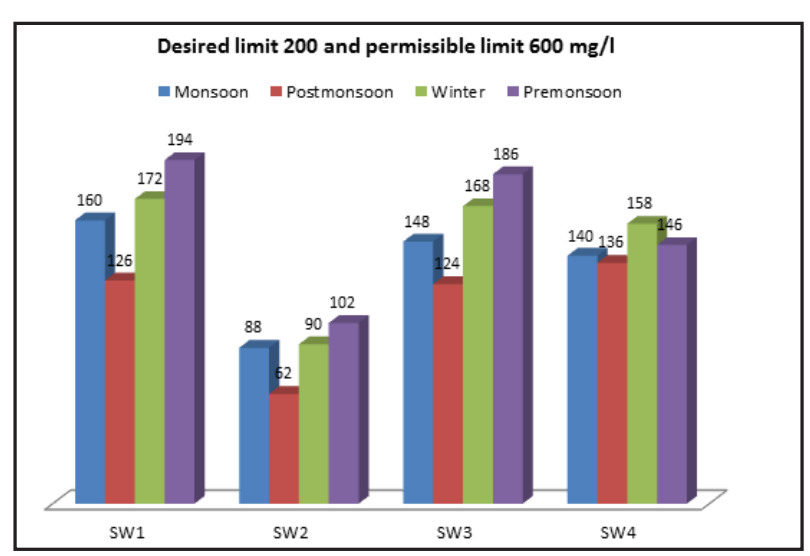

Fig. 4 Alkalinity (mg/l) for all locations.

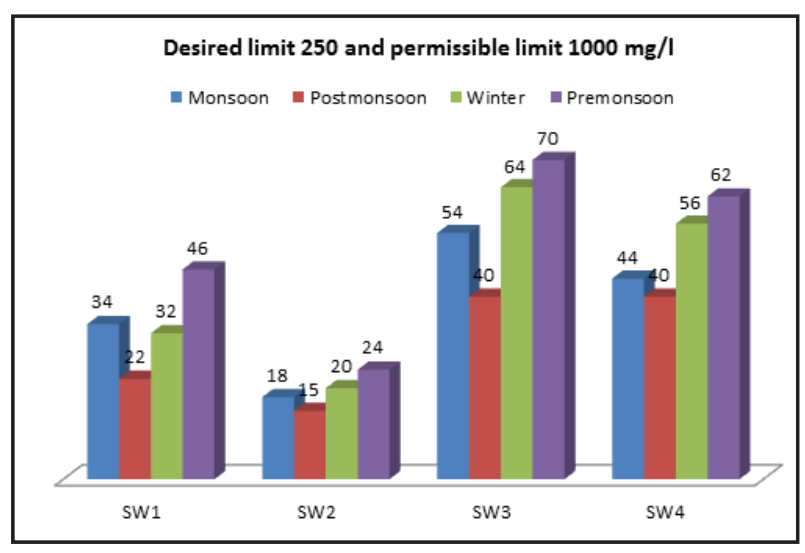

Fig. 5 Chloride (mg/l) for all locations.

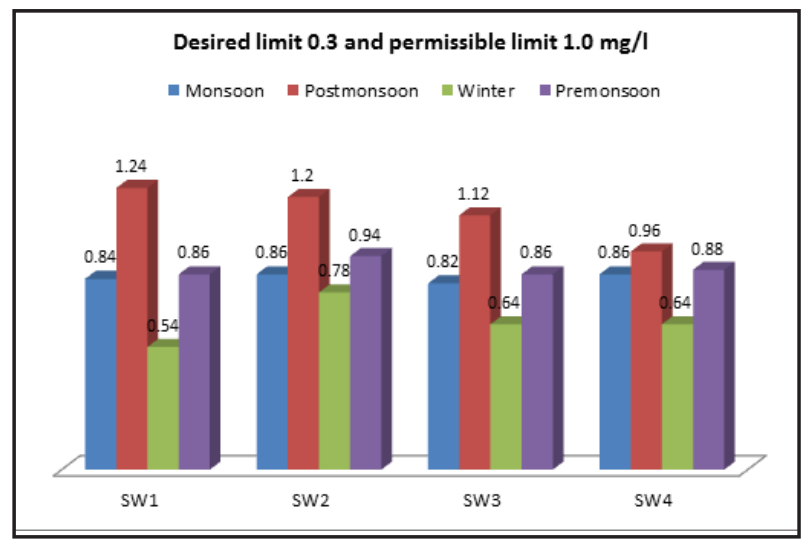

Fig. 6 Iron (mg/l) for all locations.

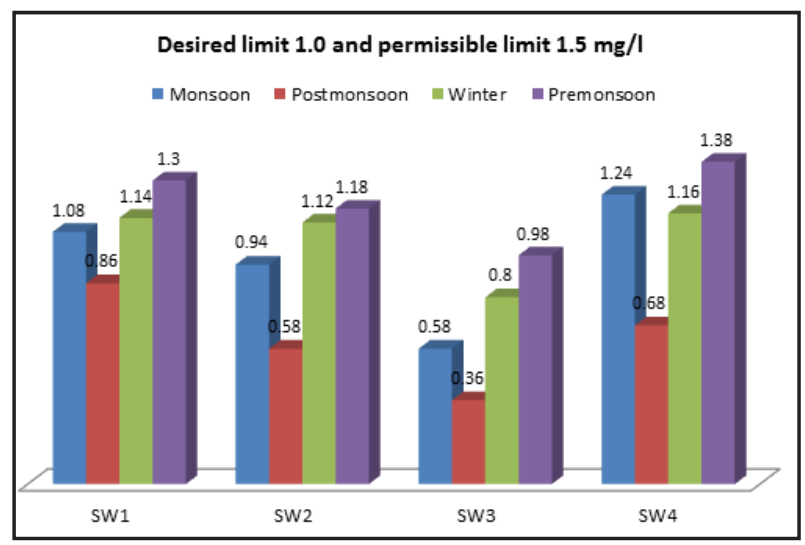

Fig. 7 Fluoride (mg/l) for all locations.

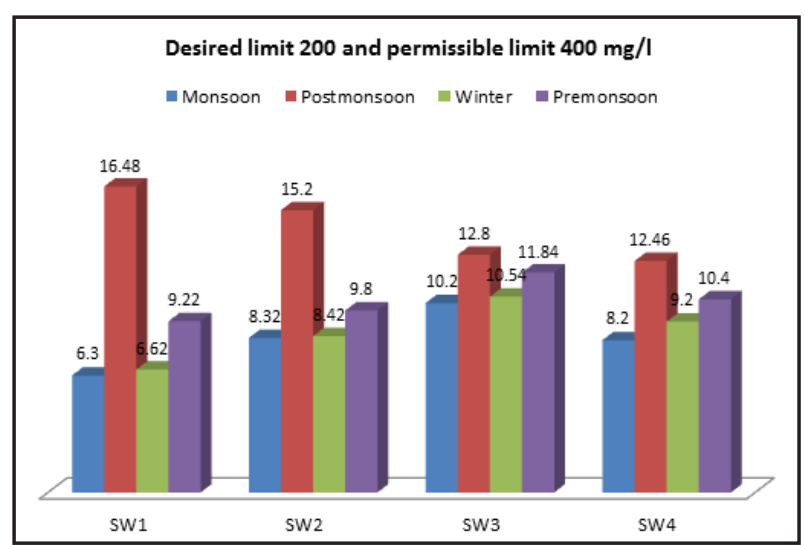

Fig. 8 Sulphate $(\mathrm{mg} / \mathrm{l})$ for all locations. 


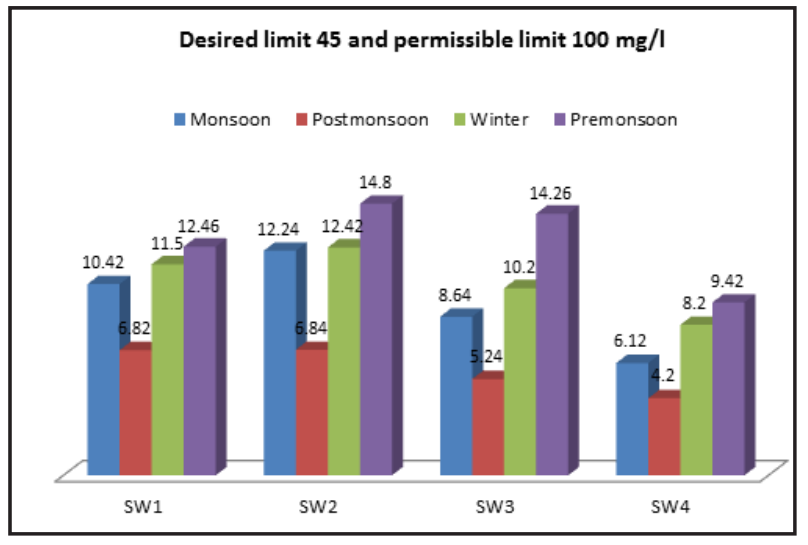

Fig. 9 Nitrate in $\mathrm{mg} / \mathrm{l}$ for all location.

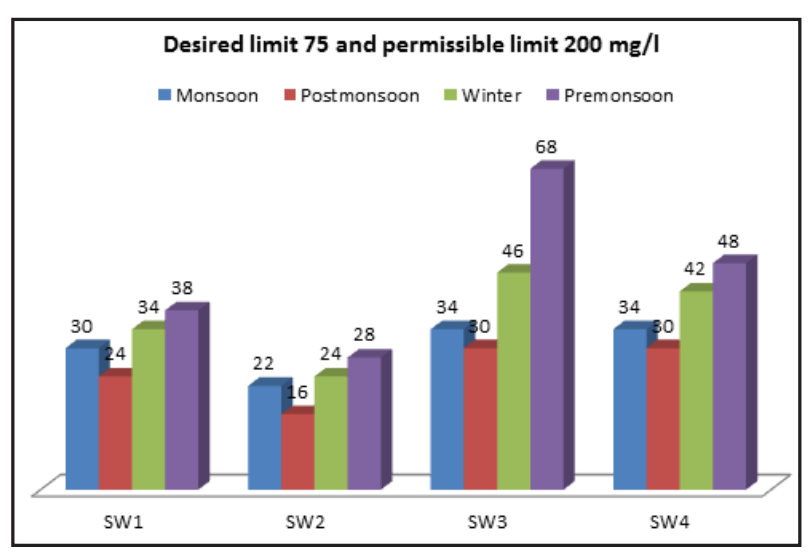

Fig. 10 Calcium in $\mathrm{mg} / \mathrm{l}$ for all locations.

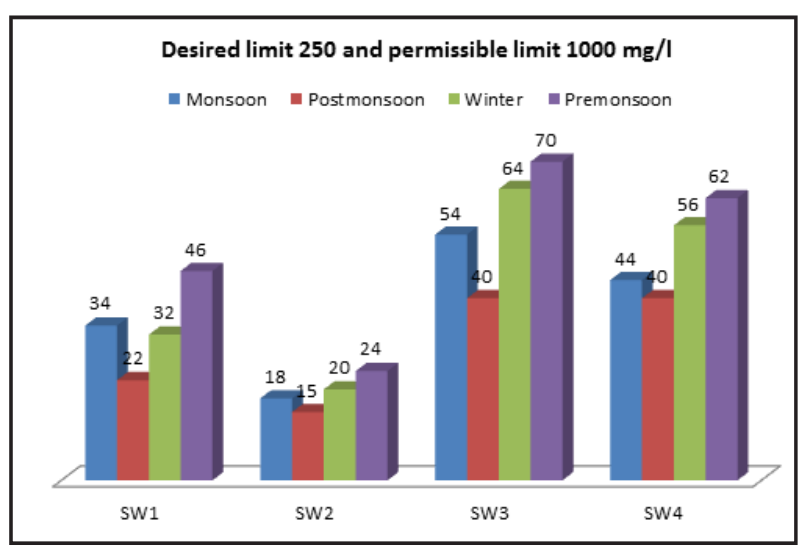

Fig. 11 Magnesium in mg/l for all locations.
The $\mathrm{pH}$ is measure of the intensity of acidity or alkalinity and concentration of hydrogen ion. The $\mathrm{pH}$ has no direct adverse effect on health. However, higher values of $\mathrm{pH}$ hastens the scale formation in water heating apparatus and also reduces germicidal potential of chloride.

High $\mathrm{pH}$ induces the formation of tri halo methane which is toxic (Jena et al., 2013). The pH values of selected water samples of present study ranged from 7.22 to 7.84 which are within the prescribed norms of standards but slightly alkaline in nature. The alkaline water can mobilize fluoride rocks with precipitation of calcium carbonates because the solubility of fluoride $\left(\mathrm{CaF}_{2}\right)$. The fluoride concentration in the site SW1, SW2 and SW4 found slightly higher than desired limit but under limit as prescribed by BIS.Some researchers carried out positive correlation of $\mathrm{pH}$ with fluoride indicates that high alkaline natures of water formats leaching of fluoride and thus effect the concentration of fluoride in water (Salve et al., 2007; Ranjan and Yasmin, 2012). The TDS, Total Hardness, Alkalinity, Chloride, Sulphate, Nitrate, Calcium and Magnesium were found well within the prescribed norms of BIS. The Iron concentration found ranged 0.54 to $1.24 \mathrm{mg} / \mathrm{l}$ which is higher than desired limit in all of the sampling stations. The Iron is generally present in atmosphere as a result of emission from the iron and power industry, thermal power plant and incineration (Sullivan, 1969). The higher concentration of iron may be due to deposition of suspended iron content mixed particulate matter from atmosphere to surface that is emitted from nearest an integrated steel and power plant. The maximum iron concentration found in the Serikheri Pond which is situated in the down wind direction with respect to the plant where dispersion of air pollutants are greater than other locations. When concentration exceed $0.1 \mathrm{mg} / \mathrm{l}$, Iron precipitate on exposure to air, decreasing pond clarity, potentially clogging irrigation pipes, and encouraging iron bacteria, which affect the flavor of both fish and water. Level of greater than $0.3 \mathrm{mg} / \mathrm{l}$ can cause 
staining on buildings and sidewalls when the water is used for irrigation.

\section{Acknowledgement}

The authors are thankful to Mr. R. N. Chakraborty, Associate General Manager (EHS), GMR Chhattisgarh Energy Limited, Raipur (C.G.) for facilitating us to carry out the present work.

\section{References}

Abdul-Razak, Asiedu, A.B., Entsua-Mensah R.E.M. and DeGraftJohnson, K.A.A. (2009) Assessment of the Water Quality of the Oti River in Ghana. West Afr. J. Appl. Ecol, 15, 45-60.

APHA (2012) Standard method for examination of water and wastewater. Am. Public Health Ass, Washington.

Bhuvana, J.P. and Ramesh, K. (2012) Water Quality Index For Assessment of Water Quality In South Chennai Coastal Aquifer, Tamil Nadu, India. Int. J. Chemi. Tech. Res., 4, 1582-1588.

BIS (2012) Indian Standard for Drinking Water Specification-10500. Bureau Ind Standards, New Delhi.

Jena V., Dixit S. and Gupta S. (2013) Assessment of water quality index of industrial area surface water sample. Int. J. Chem. Tech. Res., 5, 278-283.

Kushwaha, B.P., Kushwaha, S.K., Rai, O.P., Kushwaha, R. and Duvedi, R. (2006) Physico-Chemical study of kelo river water in Raigarh Town, Chhattisgarh. National Life Sci., 3, 569-572.

Kushwaha, B.P., Kushwaha, S.K., Duvedi, R., Singh, R. and Kushwaha, R. (2008) A study on water quality of river Umrar at umaria municipality. Ind. J. Environl. Prot., 28, 25-30.

Mehta, K.V. (2011) Physicochemical and statistical evaluation of groundwater of some places of Deesataluka in Banaskantha district of Gujarat state (India). Int. J. Chem. Tech. Res., 3, 1129-1134.
Moharir, A., Ramteke, D.S., Moghe, C.A., Wate S.R. and Sarin, R. (2002) Surface and ground water quality assessment in Bina Region. Ind. J. Environ. Prot., 22, 961-971.

Nkansah, M. A. and Ephrain, J. H. (2009) Physicochemical Evaluation of the Water From Boreholes Selected from $\mathrm{E} J$ and BAK Districts of the Ashanti Region of Ghana, Thammasat. Int. J. Sci. Tech., 14, 64-73.

Rao, V.S., Prasanthi S., Shanmukha, K.J.V. and Prasad, K.R.S. (2012) Physicochemical analysis of water samples of Nujendla area in Guntur District, Andhra Pradesh, India. Int. J. Chem. Tech. Res., 4, 691-699.

Rathod, S.D., Mohsin, M. and Farooquim (2011) Water Quality Index In \& Around Waluj - Shendra Industrial Area Aurangabad (M.S.). As, J. Biochem. Pharmaceut. Res. 1, 368-372.

Ranjan Sumit and Yasmin Shahla (2012) Assessment of Ground water quality in Gaya region with respect to Fluoride. J. Ecophysiol. Occup. HIth. 12, 21-25.

Ravichandran, C., Alagappa, A., Girish, K., Chakravarthy, P. and Sharma, P. Drinking Water Quality Assessment in Few Selected Pilgrim Centres and tourist Spots in Tamil Nadu. IJEP, 22, 129-136.

Salve, P.R., Maurya, A., Ramteke, D.S. and Wate, S.R. (2008) Fluoride and other inorganic constituents in ground water. IJEP, 28, 45-48.

Sullivan, R.J. (1969) Air pollution aspects of iron and its compounds. Contract prepared by Litton Systems, Bethesda, MD, for the National Air Pollution Control Administration, U.S. Department of Health, Education and Welfare. Nat. Tech. Inf. Service Publ. No. 188088.

Yisa, J. and Jimoh, T. (2010) Analytical Studies on Water Quality Index of River Landzu. Am. J. Appl. Sci., 7, 453-458. 